\title{
Upregulation of BDNF mRNA Expression in the Barrel Cortex of Adult Mice after Sensory Stimulation
}

\author{
Nativitat Rocamora, ${ }^{1}$ Egbert Welker, ${ }^{2}$ Marta Pascual, ${ }^{1}$ and Eduardo Soriano ${ }^{1}$ \\ ${ }^{1}$ Department of Animal and Plant Cell Biology, Faculty of Biology, University of Barcelona, 08028 Barcelona, Spain, and \\ 2/nstitute of Anatomy, University of Lausanne, 1005 Lausanne, Switzerland
}

Upregulation of brain-derived neurotrophic factor (BDNF) mRNA expression by neuronal activity has been reported in cultured hippocampal cells and in different in vivo excitotoxic paradigms. The aim of the present study was to determine whether sensory stimulation of the whisker-to-barrel pathway alters BDNF mRNA expression in the cortex and, if so, to evaluate the specificity of this effect. To this end, a set of mystacial whiskers was unilaterally stimulated by mechanical deflection, and the expression of BDNF mRNA was analyzed in the barrel cortex by in situ hybridization (ISH) using a ${ }^{35} \mathrm{~S}$ labeled antisense BDNF riboprobe and emulsion autoradiography. A clear-cut and specific upregulation of the BDNF mRNA expression was found at the level of the somatosensory cortex after the increased peripheral stimulation. In the barrel cortex of control mice, BDNF mRNA was present in a few cells in layers
$\mathrm{II} / \mathrm{II}$ and $\mathrm{VI}$, whereas it was almost undetectable in layer IV. After $6 \mathrm{hr}$ of whisker stimulation, increased levels of BDNF mRNA were found in layers II to VI of the contralateral barrel cortex. In layer IV, BDNF upregulation was confined to the barrels corresponding to the stimulated follicles. ISH combined with immunocytochemistry against the three calcium-binding proteins parvalbumin, calretinin, and calbindin- $\mathrm{D}_{28 \mathrm{~K}}$ revealed that BDNF mRNA-expressing cells do not belong to the GABAergic cell population of the barrel cortex. The present results support a role for BDNF in activity-dependent modifications of the adult cerebral cortex.

Key words: in situ hybridization; immunocytochemistry; neurotrophins; GABAergic cells; activity-dependent plasticity; habituation; somatosensory cortex; whisker stimulation
Neurotrophic factors are involved in the survival, differentiation, and maintenance of neuronal cells and their circuits (for review, see Barde, 1989; Korsching, 1993; Davies, 1994). Although for a long time nerve growth factor (NGF) was the only isolated molecule to show neurotrophic activities (Levi-Montalcini, 1987), to date three other molecules closely related to NGF have been identified: brain-derived neurotrophic factor (BDNF) (Barde et al., 1982, Leibrock et al., 1989), neurotrophin-3 (NT3) (Ernfors et al., 1990; Hohn et al., 1990; Maisonpierre et al., 1990; Rosenthal et al., 1990), and neurotrophin-4/5 (NT4/5) (Berkemeier et al., 1991; Hallböök et al., 1991; Ip et al., 1992), together forming the neurotrophin family.

Much experimental evidence has proven a functional involvement of neurotrophins in the development of the vertebrate nervous system (for review, see Barde, 1989; Davies, 1994; Snider, 1994). Moreover, the presence of neurotrophins in the adult brain, together with their regulation by neuronal activity (Zafra et al., 1990, 1991, 1992; Lu et al., 1991) and their local presynaptic effects (Lohof et al., 1993; Knipper et al., 1994; Kang and Schuman, 1995), suggests that they could be involved in the activitydependent plasticity of the adult nervous system.

Upregulation of BDNF and NGF mRNA expression and down-

Received Feb. 23, 1996; revised April 22, 1996; accepted April 24, 1996.

This work was supported by grants from the Ministry of Science and Education (SAF 94/743), the Spanish Ministry of Health (FIS 93/369), and Swiss National Science Foundation 31-39184.93. N.R. was supported by the Spanish Ministry of Science and Education. We dedicate this paper to Hendrik Van der Loos, whose enthusiasm for whisker stimulation was sadly missed in the final part of this study. We thank N. Trapp for help in the histology.

Correspondence should be addressed to Dr. Nativitat Rocamora, Department of Animal and Plant Cell Biology, Faculty of Biology, University of Barcelona, Diagonal 645, 08028-Barcelona, Spain.

Copyright (C) 1996 Society for Neuroscience $0270-6474 / 96 / 164411-09 \$ 05.00 / 0$ regulation of NT-3 were found in seizure-inducing paradigms (Gall and Isackson, 1989; Ballarín et al., 1991; Isackson et al., 1991; Dugich-Djordjevic et al., 1992; Rocamora et al., 1992, 1994; Berzaghi et al., 1993) and also after hypoglycemic coma and ischemia (Lindvall et al., 1992; Takeda et al., 1993). A more physiological paradigm was used by Castrén et al. (1992) in their study of neurotrophin expression in the visual cortex of the rat. In contrast to this study, in which the effect of a sensory deprivation was examined, we tested whether BDNF mRNA expression in the sensory cortex could be modified by increased levels of peripheral stimulation. To this end, we used the whisker-to-barrel pathway of the mouse, in which a one-to-one correspondence has been shown between a whisker follicle and its corresponding barrel, i.e., a multineuronal cell assembly in layer IV of the somatosensory cortex (Welker, 1976; Simons, 1978; Melzer et al., 1985; Chmielowska et al., 1986; Armstrong-James and Fox, 1987). A set of whiskers was stimulated in the Lausanne whisker stimulator (Melzer et al., 1985) for various time periods, and ISH for the detection of BDNF mRNA was performed. To characterize the cells expressing BDNF, ISH for the detection of BDNF mRNA was combined with immunocytochemistry against the three calcium-binding proteins parvalbumin, calretinin, and calbindin$\mathrm{D}_{28 \mathrm{~K}}$, markers of three different, nonoverlapping GABAergic cell populations, together accounting for a great majority of the cortical GABAergic interneurons (Celio, 1990).

A part of this study has appeared in abstract form (Rocamora et al., 1993).

\section{MATERIALS AND METHODS}

Whisker stimulation. Adult mice of the ICR-derived NOR strain (Van der Loos et al., 1986) were anesthetized with $60 \mathrm{mg} / \mathrm{kg}$ Nembutal, and small metal rods were glued onto whiskers B1-3 and C1-3 of the left whisker- 
pad; other whiskers were left intact (for nomenclature, see Van der Loos and Woolsey, 1973). After recovery, animals were placed in the Lausanne whisker stimulator (Melzer et al., 1985) in which they moved freely while being exposed to magnetic field bursts (frequency $9 \mathrm{~Hz}$, intensity $7 \times 10^{3}$ $\mathrm{A} / \mathrm{m}$, root mean square, burst duration $40 \mathrm{msec}$, during which the coil was energized with $\mathrm{AC}, 50 \mathrm{~Hz}$, from the mains) for different time periods (4, 6,24 , and $72 \mathrm{hr}$ ). In another group of mice, a metal rod was glued onto a single whisker (C2) under the same anesthetic conditions, and animals were stimulated for $6 \mathrm{hr}$. Mice were placed in the electromagnetic coil without it being switched on and were used as controls, together with nontreated mice (Table 1). During the stimulation period, animals were regularly checked for the presence of metal rods and whiskers, and only the whiskers that had the rods glued on all the time were considered stimulated. After the stimulation period, animals were anesthetized with Nembutal and transcardially perfused with $4 \%$ paraformaldehyde in phosphate buffer (PB; $0.12 \mathrm{M}, \mathrm{pH}$ 7.4). Then, brains were removed, post-fixed in the same fixative overnight, cryoprotected with $30 \%$ sucrose, and frozen in dry ice. Coronal and tangential (to the pial surface overlying the barrel cortex) sections ( $20 \mu \mathrm{m}$ thick) were obtained and stored in a cryoprotective solution (30\% glycerol, $30 \%$ ethylene glycol, $40 \% 0.1 \mathrm{M}$ $\mathrm{PB}, \mathrm{pH}$ 7.2), at $-70^{\circ} \mathrm{C}$ until further processed. Table 1 further defines the material used in the present study.

In situ hybridization histochemistry. In situ hybridization (ISH) on free-floating tissue sections was performed with ${ }^{35} \mathrm{~S}$-labeled antisense BDNF riboprobe. A PCR II plasmid containing a PCR-amplified fragment corresponding to nucleotides 444-827 of the mouse BDNF cDNA sequence (Hofer et al., 1990) was used to transcribe antisense and sense riboprobes. For the antisense riboprobe, plasmid was linearized with the restriction enzyme $X b a \mathrm{I}$ and transcription was performed with SP6; for the sense probe, linearization was done with HindIII and transcription was done with T7. The transcription protocol of the Promega Riboprobe kit was followed.

Free-floating sections were processed for ISH essentially as described by Isackson et al. (1991). Briefly, sections were rinsed twice in PBS $(0.1$ м PB, $150 \mathrm{~mm} \mathrm{NaCl}, \mathrm{pH} 7.6$ ), treated for $10^{\prime}$ with $0.2 \mathrm{~N} \mathrm{HCl}$, acetylated for $10^{\prime}$ in $0.1 \mathrm{M}$ triethanolamine, $\mathrm{pH} 8.0$, with $0.25 \%$ acetic anhydride, and prehybridized for $3 \mathrm{hr}$ at $55^{\circ} \mathrm{C}$ in a solution containing $50 \%$ formamide, $0.62 \mathrm{M} \mathrm{NaCl}, 20 \mathrm{~mm}$ PIPES, $\mathrm{pH} 6.8,10 \%$ dextran sulfate, $0.2 \%$ sodium dodecyl sulfate, $10 \mathrm{~mm}$ EDTA, $50 \mathrm{~mm}$ dithiothreitol, $5 \times$ Denhardt's, and $250 \mathrm{mg} / \mathrm{ml}$ sheared salmon sperm DNA. Prehybridization solution was replaced by a fresh one, to which $250 \mathrm{mg} / \mathrm{ml}$ yeast tRNA and the BDNF ${ }^{35}$ S-labeled riboprobe $\left(10-20 \times 10^{6} \mathrm{cpm} / \mathrm{ml}\right)$ were added. After overnight hybridization at $55^{\circ} \mathrm{C}$, sections were washed at room temperature (RT) in $2 \times$ SSC, incubated with $10 \mathrm{mg} / \mathrm{ml}$ RNase A in $10 \mathrm{~mm}$ Tris, $\mathrm{pH} 7.5,5 \mathrm{~mm}$ EDTA, $0.5 \mathrm{M} \mathrm{NaCl}$ for $1 \mathrm{hr}$ at $37^{\circ} \mathrm{C}$, and washed in $50 \%$ formamide $0.5 \times$

Table 1. Animals and treatments

\begin{tabular}{llll}
$\begin{array}{l}\text { Stimulation } \\
\text { periods }\end{array}$ & $\begin{array}{l}\text { Whiskers } \\
\text { (left) }\end{array}$ & Coronal & Tangential \\
\hline Control & - & 2 & - \\
$0 \mathrm{hr}$ & B1-3 and C1-3 & 1 & 1 \\
$4 \mathrm{hr}$ & B1-3 and C1-3 & 1 & 1 \\
& B1-3 and C1-3 & $6(3)$ & $5(3)$ \\
$6 \mathrm{hr}$ & B3 and C2-3 & - & 1 \\
& C2 & - & $3(2)$ \\
$24 \mathrm{hr}$ & B1-3 and C1-3 & 1 & 1 \\
$72 \mathrm{hr}$ & B1-3 and C1-3 & - & 1
\end{tabular}

Animals $(n=24)$ used in the present study. Attending to the stimulation periods, we defined five different groups of mice (column 1). In column 2, we indicated on which whiskers metal pieces were found to be present at the end of the stimulation period. Columns 3 and 4 indicate the orientation in which the brains were cut: in a coronal plane or in a plane tangential to the pial surface overlying the barrel cortex. In the first group, two mice did not receive any treatment (control), two other mice were anesthetized and metal rods were glued onto whiskers C1-3 and B1-3, but were not stimulated $(0 \mathrm{hr})$. All the animals were processed for ISH to detect BDNF mRNA. On some animals of the third group $(6 \mathrm{hr})$, indicated in parentheses, the combined ISH for BDNF and ICC against calcium-binding proteins (parvalbumin, calretinin, or calbindin) was performed. When its brain was cut coronally, each animal indicated in parentheses was used for the combined ISH-ICC with each of the three antibodies (parvalbumin, calretinin, and calbindin); when cut tangentially, only one antibody was used per animal. In mice stimulated on a single whisker (C2), only parvalbumin and calbindin were used for the combined ISH-ICC
SSC for $3 \mathrm{hr}$ at $55^{\circ} \mathrm{C}$, and in $0.1 \times \mathrm{SSC} 0.5 \%$ sarkosyl for $1 \mathrm{hr}$ at $60^{\circ} \mathrm{C}(10$ mм $\beta$-mercaptoethanol was present in all the washing solutions). Thereafter, sections were mounted onto gelatinized slides, air-dried, dehydrated through a graded ethanol series containing $0.3 \mathrm{~m}$ ammonium acetate, and dipped in autoradiographic emulsion (NTB-2, Kodak). After 5-6 weeks exposure, emulsion was developed with Kodak D19, and sections were counterstained with Nissl-staining procedure. Slides were finally dehydrated and coverslipped with dextropropoxyphene.

Specificity of the ISH signal was confirmed by comparison of the hybridization patterns obtained with previously published ones and by the lack of signal when ${ }^{35} \mathrm{~S}$-labeled sense BDNF riboprobe was used (described above).

Quantitative analysis of the autoradiographic signal was performed in coronal sections from four animals stimulated for $6 \mathrm{hr}$. BDNF mRNA hybridization level for each animal was determined by using the average of the observations made in at least four different coronal sections. Both the number of BDNF mRNA-positive cells per layer and the intensity of autoradiographic signal per single cell (cells with 10-19, 20-29, 30-39, and $\geq 40$ silver grains) were determined for the different layers of the barrel cortex (II/III, IV, and V/VI). The number of silver grains over Nissl-stained cell bodies was counted through a cortical column $(250 \mu \mathrm{m}$ wide, centered on the stimulated area of the barrel cortex) extending from layers II to VI of the somatosensory cortex using a $40 \times$ objective. Because the autoradiographic background was found to be $\sim 2-4$ silver grains/cell body, only cells displaying $>10$ silver grains were considered as BDNF mRNA-positive cells. Increased levels of BDNF mRNA were estimated by comparing quantitative data from the stimulated barrelfield with respect to the unstimulated (control) side. The statistical significance of the obtained differences was tested by one-way ANOVA. The barrel cortex of unstimulated animals placed or not placed in the electromagnetic coil (without it being switched on) was also used as control.

Double ISH-immunocytochemistry procedure. Immunoperoxidase detection of the calcium-binding proteins parvalbumin, calretinin, and calbindin- $\mathrm{D}_{28 \mathrm{~K}}$ was performed on tissue sections previously hybridized with ${ }^{35} \mathrm{~S}$-labeled antisense BDNF riboprobe. After the last ISH wash $\left(0.1 \times \mathrm{SSC}, 60^{\circ} \mathrm{C}\right)$, sections were kept at RT, thoroughly rinsed in PBS, and incubated in a blocking solution containing $10 \%$ normal goat serum and $4 \%$ bovine serum albumin (BSA) in PBST $(0.2 \%$ Triton X-100 in PBS) for $1 \mathrm{hr}$ at RT. After rinsing, sections were incubated overnight at $4{ }^{\circ} \mathrm{C}$ with one of the following primary antibodies in PBST containing 5\% normal serum and $0.5 \%$ BSA: rabbit anti-parvalbumin (PARV, 1:1000), rabbit anti-calbindin- $\mathrm{D}_{28 \mathrm{~K}}$ (CALB, 1:1500), and rabbit anti-calretinin (CALR, 1:1000). Thereafter, sections were sequentially incubated with biotinylated goat anti-rabbit antibodies (1:200) and with the avidinbiotin-peroxidase complex (ABC, 1:200). Peroxidase was developed with $0.05 \%$ diaminobenzidine in $0.1 \mathrm{M} \mathrm{PB}$ and $0.005 \%$ hydrogen peroxide. Thereafter, immunoreacted sections were mounted onto gelatinized slides, dipped in autoradiographic emulsion, and processed as described above.

\section{RESULTS \\ Upregulation of BDNF mRNA expression in the barrel cortex after whisker stimulation}

The BDNF mRNA hybridization pattern in the cortex of control mice showed a nonhomogeneous distribution, both among the different cortical areas and in different layers. In general, levels of this mRNA were higher in ventrolateral than in dorsomedial cortex. However, the barrel cortex had lower levels of BDNF mRNA than its neighboring areas, including cingulate and retrosplenial cortices (not shown). In the cerebral cortex, BDNF mRNA was preferentially expressed in cells in layers II/III and V/VI. This distribution was also found in the barrel cortex, although fewer cells in layers II/III and V/VI expressed BDNF. In control mice, BDNF mRNA was almost undetectable in layer IV, which, in contrast, contains the highest density of cells (Fig. 1). Comparison of the distribution of silver grains and the underlying Nissl-stained image showed no evidence for the accumulation of silver grains above glial cells.

Unilateral stimulation of a set of whiskers for different time periods (4-72 hr) induced increased levels of BDNF mRNA through layers II to VI of the contralateral barrel cortex. The 

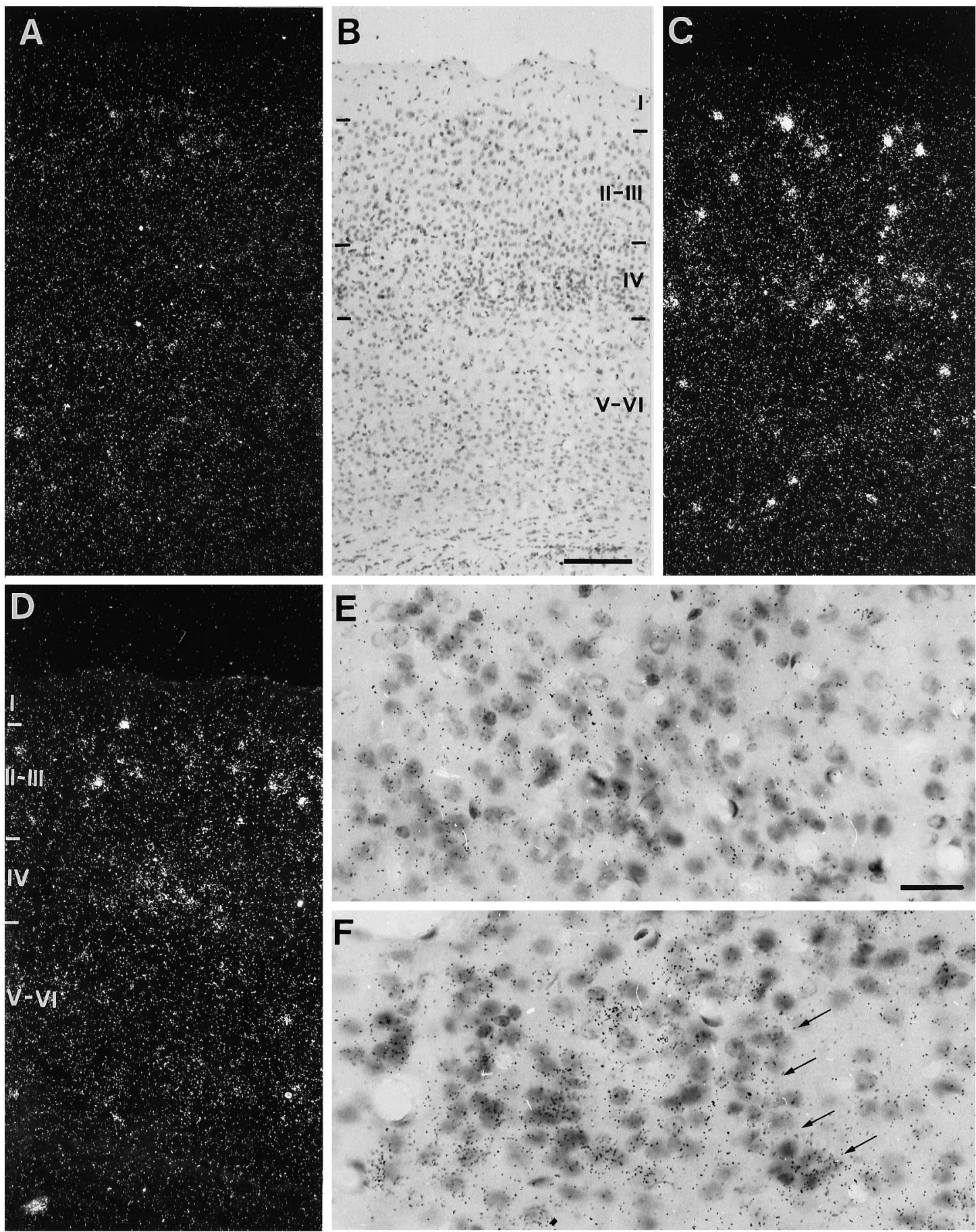

Figure 1. BDNF mRNA expression in the barrel cortex after unilateral stimulation of the contralateral whiskerpad. Whiskers B1-3 and C1-3 were unilaterally stimulated for different time periods, and BDNF mRNA expression was analyzed on coronal sections through the contralateral barrel cortex. $A, C$, and $D$ are dark-field photomicrographs of control $(A)$ and stimulated barrel cortex for different time periods: $6 \mathrm{hr}(C)$ and $24 \mathrm{hr}(D)$. $B$ is a bright-field photomicrograph of the Nissl-stained section shown in $C$. Roman numbers I, II/III, IV, and V/VI in $B$ and $D$ indicate layers in the barrel cortex. Note higher BDNF mRNA levels in $C$ (6 hr stimulation) than in $D$ (24 hr stimulation). $E$ and $F$ are higher-magnification bright-field photomicrographs showing BDNF mRNA hybridization signal (black silver grains) in layer IV of control $(E)$ and 6 hr stimulated $(F)$ barrel cortices. Arrows in $F$ indicate a wall of a barrel. Note the clear upregulation of BDNF mRNA expression in cells in $F$ compared with $E$. Scale bar (shown in $B$ ) is $150 \mu \mathrm{m}$ and pertains to $A-D$; scale bar (shown in $E$ ) is $25 \mu \mathrm{m}$ and pertains also to $F$.

ipsilateral, unstimulated barrel cortex showed a pattern and levels of BDNF mRNA expression similar to that in barrel cortex of control animals. The upregulation of BDNF mRNA expression was maximal after $6 \mathrm{hr}$ stimulation. Both longer (24-72 hr) and shorter $(4 \mathrm{hr})$ stimulation periods resulted in lower levels of this
mRNA (Fig. 1). We therefore decided to use the $6 \mathrm{hr}$ stimulation period for more detailed analysis.

Quantitative analysis of the autoradiographic signal (through a cortical column $250 \mu \mathrm{m}$ wide) showed an average of $33.1 \pm 7.3$ cells expressing BDNF in layer IV of the stimulated barrel cortex 
A

\begin{tabular}{c|cc} 
LAYERS & CONTROL & STIMULATED \\
\hline II- III & $10.4 \pm 3.4$ & $20.6 \pm 5.3^{*}$ \\
IV & $1.8 \pm 1.2$ & $33.8 \pm 8.7^{* *}$ \\
V-VI & $8.1 \pm 3.5$ & $13.0 \pm 3.4^{*}$
\end{tabular}

B

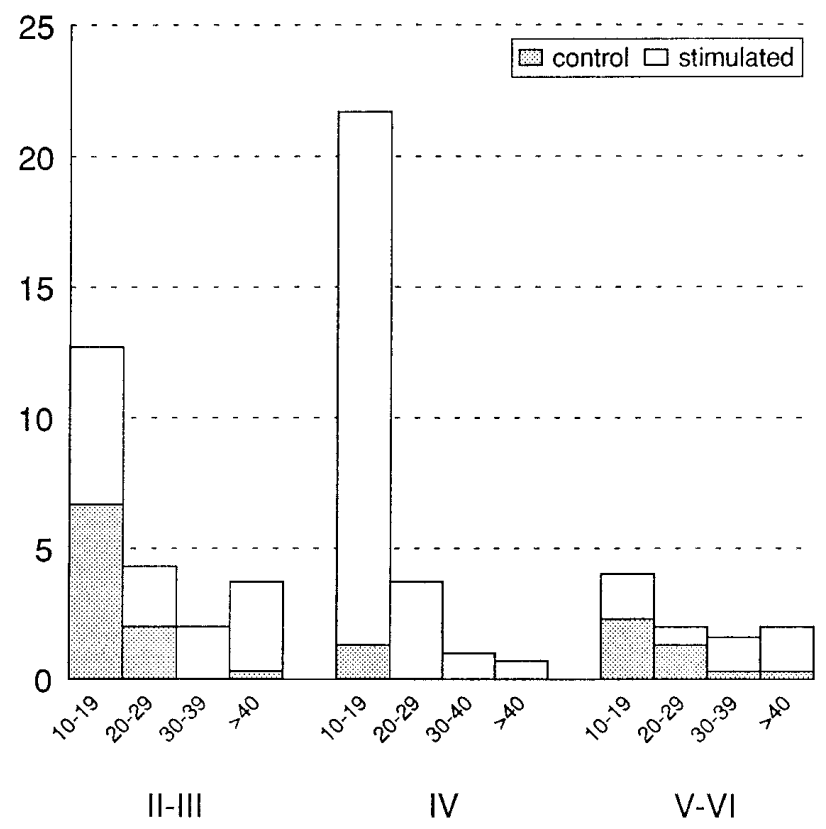

Figure 2. Quantification of the BDNF mRNA hybridization signal through the different layers of the barrel cortex. BDNF mRNA levels were measured in a cortical column $250 \mu \mathrm{m}$ wide. Levels in contralateral (stimulated) and ipsilateral (control) barrel cortex are compared. In $A$, results are expressed as the mean of the medians of the number of cells expressing BDNF mRNA (with $\geq 10$ silver grains over soma) in the different cortical layers (II/III, IV, and V/VI) of ipsilateral and contralateral barrel cortices \pm the SD. Numbers represent the averaged levels of four different animals in which whiskers B1-3 and C1-3 were stimulated for a period of $6 \mathrm{hr}$. Asterisks denote statistically significant differences between contralateral and ipsilateral barrel cortex by the ANOVA test $\left({ }^{*} p\right.$ $\leq 0.05, * * p \leq 0.001$ ). In $B$, not only the number of labeled cells but also the levels of BDNF mRNA hybridization signal (BDNF mRNAexpressing cells were classified as cells with $10-19,20-29,30-39$, and $\geq 40$ grains/cell) were represented in the different cortical layers for a $6 \mathrm{hr}$ stimulated animal.

compared with the near absence of labeled cells (average $1.9 \pm$ 0.8 ) in the corresponding area of the unstimulated side and in control animals. The number of BDNF-expressing cells increased approximately twofold $(19.4 \pm 4.68$, respect to control level 11.2 $\pm 3.47)$ in layer II/III and one and a half-fold $(13 \pm 1.47$ respect to control $8.5 \pm 1.2$ ) in layers V/VI (Fig. $2 A$ ). Not only the number of BDNF mRNA-expressing cells (as cells with $>10$ silver grains over the soma) but also the average intensity of BDNF mRNA autoradiographic signal per labeled cell increased (Fig. $2 B$ ).

\section{Increased levels of BDNF mRNA in layer IV are restricted to the stimulated barrels}

Because individual barrels cannot be easily identified in coronal sections, we used tangential sections to determine whether BDNF mRNA upregulation was restricted to the barrel area corresponding to the stimulated whisker. Tangentially cut sections were from animals in which either a single whisker (C2) or several whiskers (C2, C3, B3) were stimulated. In both cases, the intensity of BDNF mRNA upregulation was similar (Fig. 3). Reconstruction of the ensemble of barrels from serial sections through layer IV revealed that the increased levels of BDNF mRNA were restricted to the barrels that correspond to the stimulated whiskers. The increased levels of BDNF mRNA were observed in neurons with their soma in the walls or in the hollows. However, not all the neurons in a stimulated barrel expressed BDNF.

\section{Immunocytochemical characterization of cells expressing BDNF mRNA in control and stimulated barrel cortex}

ISH for the detection of BDNF mRNA and immunocytochemistry against one of the three calcium-binding proteins PARV, CALR, or CALB were sequentially performed in the same tissue sections. The specific patterns of both BDNF mRNA-hybridization signal and calcium-binding protein-immunoreactivity were preserved after the combined procedure (Fig. 4).

PARV-immunoreactive cells were present in barrel cortex from layers II to VI, with the highest density in layer IV. In a tangential section $(20 \mu \mathrm{m})$ at medial layer IV, we counted 20-25 PARVpositive cells per individual barrel (B1-3 or C1-3, see Fig. 4F). CALR immunocytochemistry labeled fewer cells, most of which located in layer II/III. There were very few CALR-positive cells in layer IV (an average of 1-2 per barrel per section). Both in control and stimulated barrel cortex, the combined ISH-immunocytochemistry protocol showed no colocalization between BDNF mRNA and any of the calcium-binding proteins parvalbumin or calretinin.

CALB immunocytochemistry revealed different populations of CALB-immunoreactive cells in the barrel cortex. Both weak and heavy CALB-immunoreactive neurons were found. Neurons that displayed weak CALB immunoreactivity, in agreement with previous studies, included stellate cells in layer IV and pyramidal neurons in layer II/III. Only a few heavy CALB-immunoreactive neurons, GABAergic interneurons, were found (Hendry et al., 1989; Celio, 1990; Van Brederode et al., 1991). Combined ISH BDNF and immunocytochemistry for CALB showed that heavy CALB-immunoreactive neurons (i.e., GABAergic) did not express BDNF either in control or after stimulation. In addition, only some of the weak CALB-immunoreactive neurons in layers II/III, but not those in layer IV, were found to express BDNF in basal conditions. After peripheral stimulation, increased levels of BDNF mRNA were found in an important proportion of the weak CALB-immunoreactive neurons of layer IV and also in layers II/III and V/VI (Fig. 4).

We thus conclude that the several classes of GABAergic neurons as identified by PARV, CALR, or heavy CALB immunoreactivity do not express BDNF mRNA either in control conditions or after stimulation. It is therefore likely that the spiny stellate cells in layer IV and some pyramidal neurons in layers II/III and $\mathrm{V} / \mathrm{VI}$ are responsible for the BDNF upregulation after sensory stimulation. 

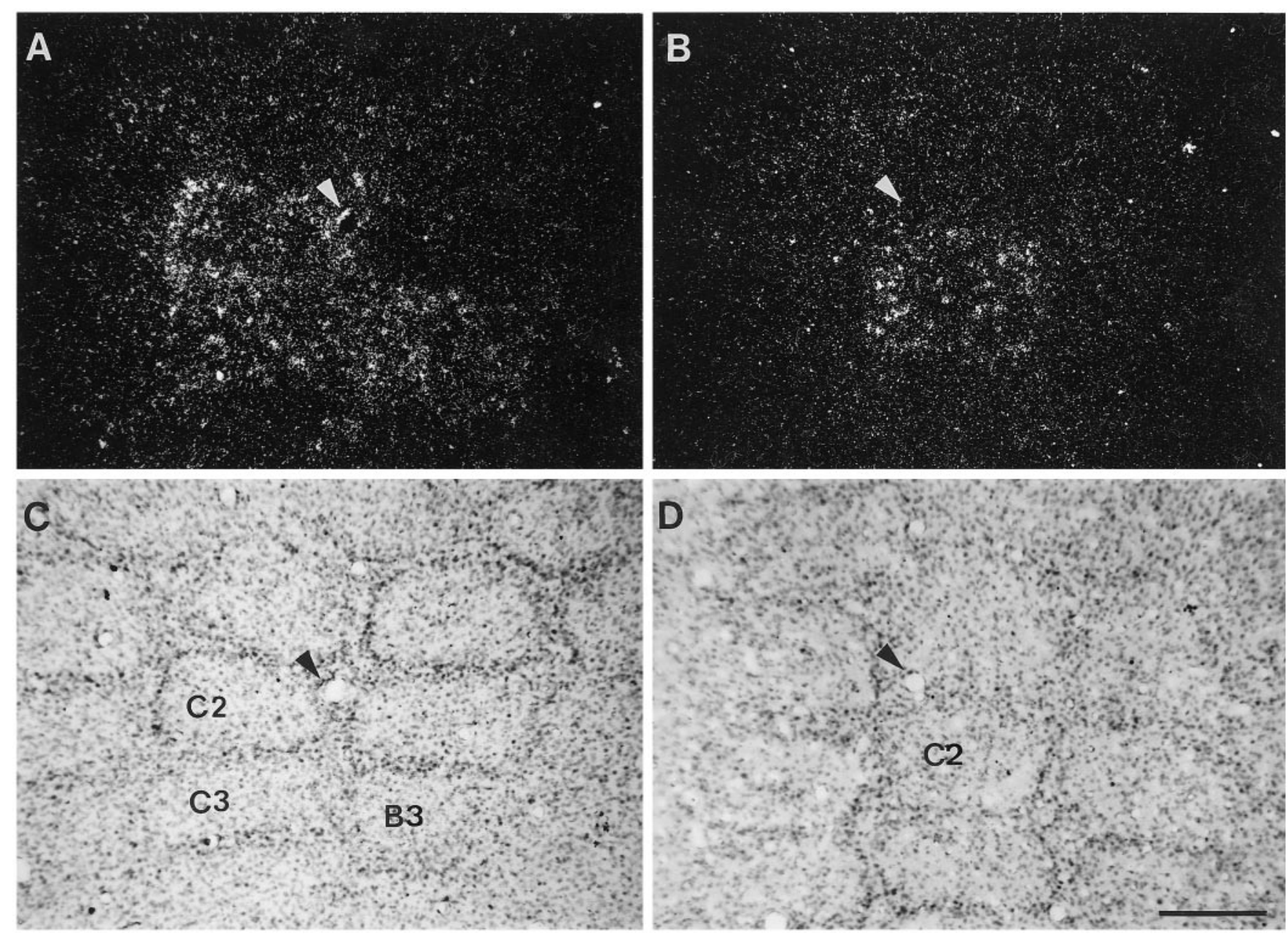

Figure 3. One-to-one relationship between the stimulated whiskers and the corresponding contralateral, stimulated barrels. $A$ and $B$ are dark-field photomicrographs showing BDNF mRNA hybridization signal in tangential sections through stimulated barrel cortices of $6 \mathrm{hr}$ stimulated animals. In $A$, several whiskers (C2, C3, and B3) were stimulated; in $B$, only one whisker (C2) was stimulated. $C$ and $D$ show the Nissl-stained sections of $A$ and $B$, respectively. Arrowheads in $A-D$ indicate blood vessels in the tissue to show correspondence between dark- and bright-field photomicrographs. Note that stimulation of whiskers results in BDNF mRNA upregulation that is restricted to the stimulated barrels. Scale bar (shown in $D$ ), $200 \mu \mathrm{m}$.

\section{DISCUSSION}

The main findings of the present study can be summarized as follows: (1) unilateral peripheral stimulation of the whisker-tobarrel pathway in adult mice increased levels of BDNF mRNA in cells of layers II to VI in the contralateral, stimulated barrel cortex; (2) BDNF upregulation in barrels of layer IV followed a one-to-one relation with the corresponding stimulated whiskers; and (3) most of the cells expressing BDNF in the barrel cortex, both after stimulation and in control conditions, were pyramidal or spiny stellate, but not GABAergic neurons.

\section{Upregulation of BDNF mRNA expression and its correlation with modified neuronal activity}

The activity-dependent modulation of the expression of BDNF has been extensively documented. Depolarization of cultured hippocampal neurons with high potassium or with glutamate receptor agonists increases levels of BDNF mRNA, whereas GABAergic transmission reduces this mRNA level ( $\mathrm{Lu}$ et al., 1991; Zafra et al., 1991). In addition to these analyses "in vitro," several "in vivo" seizure-inducing paradigms also resulted in a clear-cut upregulation of BDNF, mainly affecting the hippocam- pal formation and cortex (Ernfors et al., 1991; Isackson et al., 1991; Dugich-Djordjevic et al., 1992; Rocamora et al., 1992, 1994). In a more physiological paradigm, decreased sensory stimulation has been shown to modify BDNF mRNA expression in the cerebral cortex. Visual deprivation (by dark rearing) for 1 week results in decreased levels of BDNF mRNA in the visual cortex, and subsequent exposure to light re-establishes normal levels of this mRNA (Castrén et al., 1992).

BDNF mRNA hybridization signal in the adult cortex of control mice showed that this mRNA was distributed in two main regions corresponding to layers II/III and VI, forming continuous bands along the different cortical areas (Isackson et al., 1991; Castrén et al., 1992; present results). It is worth noting that the barrel cortex had a lower level of BDNF mRNA than its adjacent cortical areas. Only a few cells in layer IV were found to express BDNF mRNA in control conditions. These low levels of BDNF mRNA could be attributable to a very efficient inhibitory control of layer IV cells, which in physiological conditions prevented BDNF mRNA expression. Interestingly, upregulation of BDNF mRNA expression in layer IV was described after intraperitoneal injection of the 

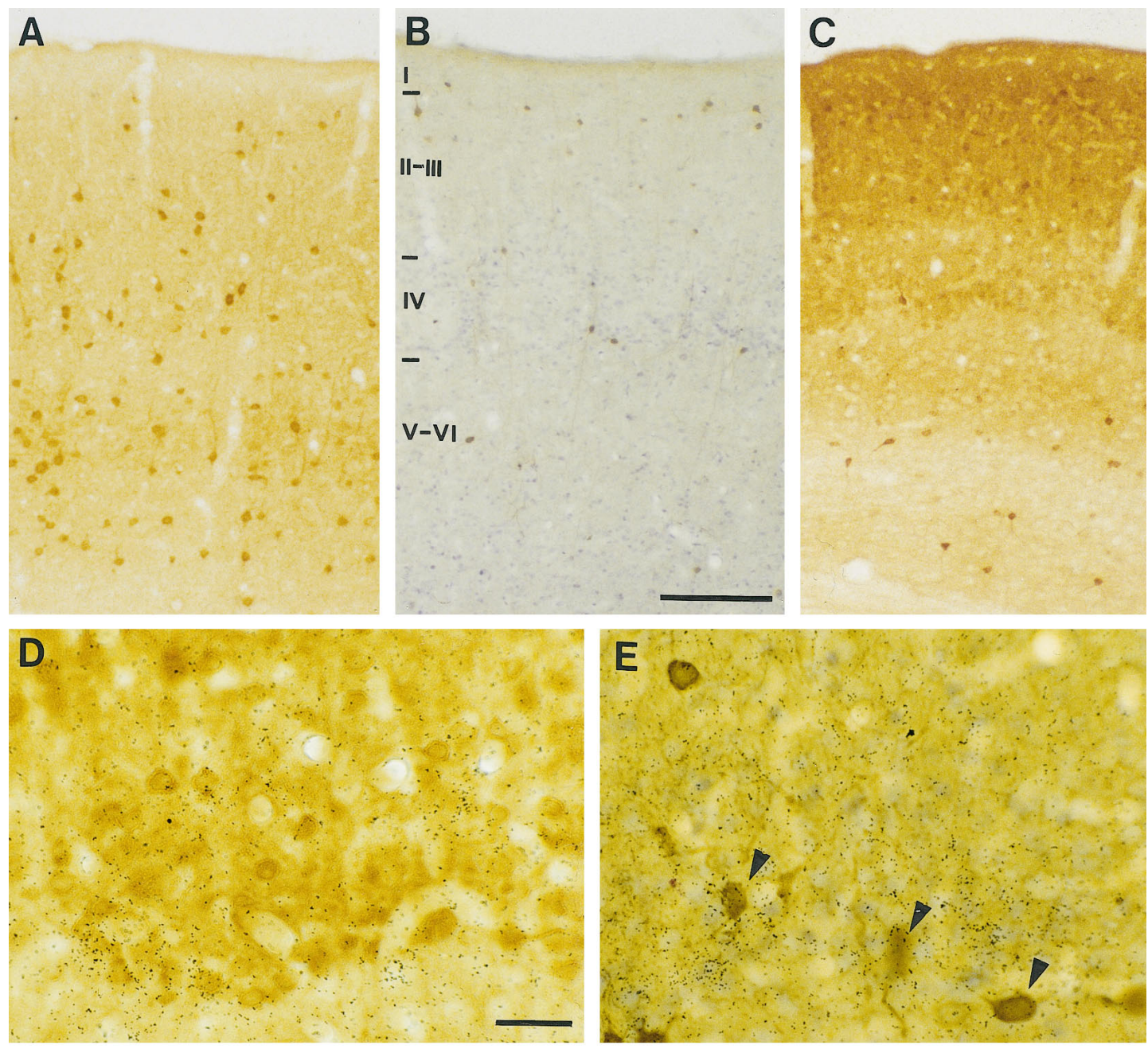

$\mathbf{F}$

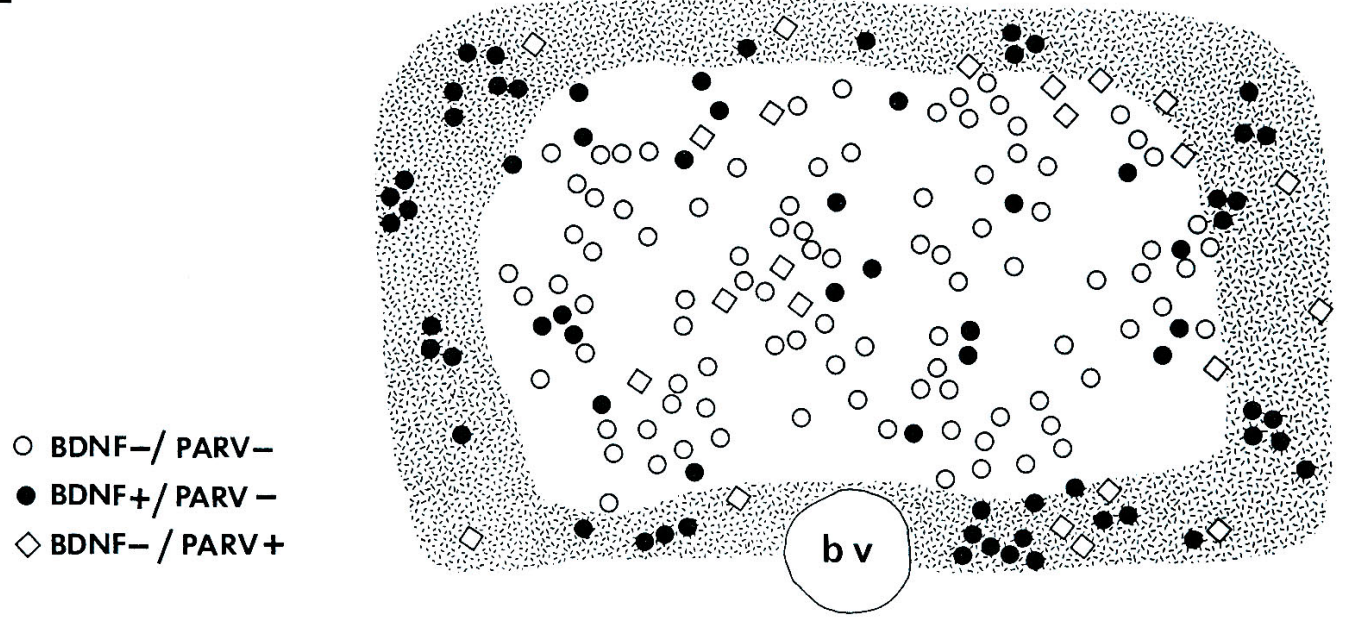

Figure 4. BDNF mRNA is not expressed in GABAergic cells of the barrel cortex. Bright-field photomicrographs of double-processed tissue: ISH for BDNF and immunocytochemistry (ICC) for each of the three different calcium-binding proteins parvalbumin $(A)$, calretinin $(B)$, and calbindin $(C)$. In $B$, calretinin-immunoreacted section was also Nissl-stained. Note that the ISH result could not be seen in $A-C$ because of the low magnification. $D$ and $E$ are higher-magnification views of coronal sections showing the combined ISH-ICC in the stimulated barrel cortex at layer IV level. In $D$, ICC was against CALB, and in $E$ against PARV. Note that the BDNF mRNA hybridization signal is not present in PARV-immunoreactive cells (arrowheads in $E)$, and that it is present in weak but not in heavy calbindin-immunoreactive neurons $(D) . F$ is a camera lucida drawing of a stimulated barrel C3 from a tangential section hybridized with BDNF and immunoreacted against PARV; $b v$ is a blood vessel. Hatched area represents the wall of the barrel, where the density of cells made it difficult to individualize them; thus, only cells with a very high level of labeling were indicated as BDNF-expressing cells. Symbols in $F$ indicate various classes of cells (see key to the left) formed by those that are positive for BDNF mRNA, or not, in combination with being immunoreactive for parvalbumin, or not. Note that there are no PARV+/BDNF+ cells. Scale bar (shown in $B$ ) is $150 \mu \mathrm{m}$ and pertains to $A-C$; scale bar (shown in $D$ ) is $25 \mu \mathrm{m}$ and also pertains to $E$. 
NMDA receptor antagonist MK-801 in rats, and this effect was abolished by the GABA agonist pentobarbital (Castrén et al., 1993).

In the present study, activity of cortical neurons was increased by mechanical stimulation of a set of mystacial whiskers. The stimulation was continuous and forms an exaggeration of sensory input to which the animal is forcefully exposed. Using the deoxyglucose (DG) method, it has been shown that such stimulation for a period of 45 min results in a local increase in DG uptake in the barrel cortex that forms, in a coronal plane, a column (Melzer et al., 1985). This radially oriented column extends through all cortical layers with its highest level in layer IV, where it is confined to the barrel that corresponds to the stimulated whisker. Evidence has been reported that an increase in DG uptake in the nervous system is related to spiking activity in the presynaptic element (Schwartz et al., 1979; Kadekaro et al., 1985). It is therefore likely that our stimulation method induces the highest increase in spiking frequency in neurons of layer IV. Analyses of single-unit activity in the barrel cortex of anesthetized mice and rats also showed layer IV cells to be the most responsive cortical neurons to whisker deflection (Simons, 1985; Armstrong-James and Fox, 1987; Welker et al., 1993).

Whisker stimulation results in an increase in BDNF mRNA expression by neurons that form a radial column from layer II to VI of the stimulated barrel cortex, comprising at the level of layer IV the barrel(s) corresponding to the stimulated whisker(s). This distribution pattern correlates well with the column of stimulusdependent DG uptake described above. Maximal increase in BDNF expression was found after $6 \mathrm{hr}$ of stimulation. It was shown that continuous whisker stimulation for $24 \mathrm{hr}$ results in a decrease in the metabolic activity in the stimulated barrel compared with the DG levels in nonprestimulated barrels (Welker et al., 1992). This effect of continuous whisker stimulation has the characteristics of cortical habituation. We suggest that BDNF mRNA upregulation after 4 and $6 \mathrm{hr}$ stimulation is the result of an increased activity of cortical neurons induced by peripheral stimulation, and that lower BDNF mRNA levels after longer stimulation periods, such as $24 \mathrm{hr}$, could be the result of lower levels of neuronal activity attributable to habituation of the cortical neurons.

Comparison of BDNF mRNA levels among the different cortical layers in control and after stimulation showed that upregulation of BDNF expression in layer IV is the most pronounced. This is not surprising because of the very low basal levels of BDNF mRNA in layer IV, together with the fact that layer IV is the cortical layer receiving the densest input from the thalamic relay nucleus (i.e., nucleus ventrobasalis of the thalamus) (Killackey, 1973; Keller et al., 1985; Chmielowska et al., 1989) and is therefore most likely to be exposed to the most "direct" effect of the increase in sensory stimulation. Thus, we conclude that cells in layer IV may have a threshold of excitation above which BDNF mRNA is upregulated. This threshold may have been established in such a way that it is not exceeded in natural conditions.

\section{GABAergic cells do not express BDNF mRNA either in control conditions or after stimulation}

To determine whether GABAergic neurons are among the cells expressing BDNF, we used the ISH for BDNF in combination with the immunocytochemical characterization of three different, nonoverlapping populations of GABAergic cells (PARV-, CALR-, and heavy CALB-immunoreactive cells). We found BDNF mRNA in control mice not to be expressed in any of these populations, which together constitute most of the GABAergic cell population. Interestingly, the same result was found in the hippocampus (Rocamora et al., unpublished data) and, for PARV-immunoreactive cells, in the adult rat visual cortex (Cellerino et al., 1995). As mentioned above, there is a broad correlation between neuronal activity and BDNF mRNA expression. However, PARV-immunoreactive cells, which are among the most active cells in the hippocampus (Kawaguchi et al., 1987), do not express BDNF (Rocamora et al., unpublished data). A similar discordance was found in the present study, where GABAergic (fast-spiking) cells of the barrel cortex, also among the most active cells (Armstrong-James et al., 1993; Welker et al., 1993), did not express BDNF either. This situation holds not only for basal activity (unstimulated) conditions but also after the increase in cortical activity. Upon peripheral stimulation, thalamic afferents activate both nonspiny (GABAergic) and spiny stellate cells in layer IV. However, BDNF mRNA expression was found upregulated only in non-GABAergic cells. Thus, other aspects apart from the neuronal activity may be involved in the differential regulation of BDNF mRNA expression in GABAergic and non-GABAergic cell populations.

Upregulation of BDNF mRNA expression was reported to be mediated mainly by activation of non-NMDA receptors in excitotoxic paradigms (Zafra et al., 1990; Ernfors et al., 1991). However, a major involvement of the NMDA receptors was found in more physiological conditions (Zafra et al., 1991). Interestingly, recordings made in the barrel cortex of urethane-anesthetized rats showed that the initial activation of fast-spiking (smooth inhibitory) cells by the thalamocortical afferents is almost exclusively mediated by the activation of non-NMDA receptors, whereas such activation of slow-spiking (spiny stellate) cells is partially mediated by NMDA receptors (Armstrong et al., 1993). Thus, this difference in the participation of the NMDA receptor in the initial activation of layer IV cells may account for the specific upregulation of BDNF mRNA in the non-GABAergic cells. Future experiments combining whisker stimulation and the use of specific antagonist to the different glutamate receptors could shed light on this hypothesis.

Other mechanisms for the specific regulation of BDNF mRNA expression in the several cell populations could involve differences in the signal transduction pathways, differential exposure of regulatory sequences to the transcriptional machinery, and/or the availability of various transcription factors.

\section{How could BDNF be involved in activity-dependent plasticity in the adult barrel cortex? A proposal}

Specific dependence of sensory neurons on different targetderived neurotrophins has been shown by the classical tests for neurotrophic activity and more recently confirmed by the analysis of null-mutated mice (for review, see Barde, 1989; Davies, 1994; Snider, 1994). However, it is still unclear whether and how these molecules are involved in survival and/or differentiation of the CNS neurons. BDNF has recently been found to be involved in the reshaping of developing thalamocortical connections in the rat visual cortex (Cabelli et al., 1995) and in the ingrowth and branching of the retinal fibers in the Xenopus laevis optic tectum (CohenCory and Fraser, 1995). Analysis of null-mutated mice showed that the differentiation of parvalbumin- and calbindinimmunoreactive neurons of the somatosensory cortex is dependent on BDNF (Jones et al., 1994). Interestingly, BDNF was shown to induce increased glutamic acid decarboxylase (GAD) immunoreactivity and GABA uptake in striatal GABAergic neu- 
rons during development (Mizuno et al., 1994). This could be of relevance in relation to the fact that chronic stimulation of the whisker-to-barrel pathway in adult mice induces increased GAD immunoreactivity in the corresponding barrels (Welker et al., 1989). BDNF may therefore be required for this aspect of adult plasticity which, in behavioral terms, results in habituation of neuronal activity to the peripheral stimulus (Welker et al., 1992). We therefore propose that BDNF, produced by non-GABAergic cells, could potentiate the role of GABAergic cells in cortical processing of sensory information and thus be involved in activitydependent modifications of cortical circuitry.

\section{REFERENCES}

Armstrong-James M, Fox K (1987) Spatiotemporal convergence and divergence in the rat S1 "barrel" cortex. J Comp Neurol 263:265-281.

Armstrong-James M, Welker E, Canahan CA (1993) The contribution of NMDA and non-NMDA receptors to fast and slow transmission of sensory information in the rat S1 barrel cortex. J Neurosci 13:2149-2160.

Ballarín M, Ernfors P, Lindefors N, Persson H (1991) Hippocampal damage and kainic acid injection induce a rapid increase in mRNA for BDNF and NGF in the rat brain. Exp Neurol 114:35-43.

Barde Y-A (1989) Trophic factors and neuronal survival. Neuron 2:1525-1534.

Barde Y-A, Edgar D, Thoenen H (1982) Purification of a new neurotrophic factor from mammalian brain. EMBO J 1:549-553.

Berzaghi MP, Cooper J, Castrén E, Zafra F, Sofroniew M, Thoenen H, Lindholm D (1993) Cholinergic regulation of brain-derived neurotrophic factor (BDNF) and nerve growth factor (NGF) but not neurotrophin-3 (NT-3) mRNA levels in the developing rat hippocampus. J Neurosci 13:3818-3826.

Berkemeier LR, Winslow JW, Kaplan DR, Nikolics K, Goedded DV, Rosenthal A (1991) Neurotrophin-5: a novel neurotrophic factor that activates trk and trkB. Neuron 7:857-866.

Cabelli RJ, Hohn A, Shatz C (1995) Inhibition of ocular dominance column formation by infusion of NT-4/5 or BDNF. Science 267:1662-1666.

Castrén E, Zafra F, Thoenen H, Lindholm D (1992) Light regulates expression of brain-derived neurotrophic factor mRNA in rat visual cortex. Proc Natl Acad Sci USA 89:9444-9448.

Castrén E, Bergazhi MP, Lindholm D, Thoenen H (1993) Differential effects of MK-801 on brain-derived neurotrophic factor mRNA levels in different regions of the rat brain. Exp Neurol 122:244-252.

Celio MR (1990) Calbindin- $\mathrm{D}_{28 \mathrm{~K}}$ and parvalbumin in the rat nervous system. Neuroscience 35:375-475.

Cellerino A, Burkhalter A, Maffei L, Domenici L (1995) Expression of trkB but not BDNF mRNA in parvalbumin containing neurons of the adult rat visual cortex. Soc Neurosci Abstr 21:2010.

Chmielowska J, Kossut M, Chmielowska M (1986) Single vibrissal cortical column in the mouse labeled with 2-deoxyglucose. Exp Brain Res 63:607-619.

Chmielowska J, Carvell GE, Simons DJ (1989) Spatial organization of thalamocortical and corticothalamic projection systems in the rat SmI barrel cortex. J Comp Neurol 285:325-338.

Cohen-Cory S, Fraser SE (1995) Effects of brain-derived neurotrophic factor on optic axon branching and remodelling in vitro. Nature 378:192-196.

Davies AM (1994) The role of neurotrophins in the developing nervous system. J Neurobiol 25:1334-1348.

Dugich-Djordjevic MM, Tocco G, Lapchak PA, Pasinetti G, Najm I, Baudry M, Hefti F (1992) Regionally specific and rapid increases in brain-derived neurotrophic factor messenger RNA in the adult rat brain following seizures induced by systemic administration of kainic acid. Neuroscience 47:303-315.

Ernfors P, Ibáñez CF, Ebendal T, Olson L, Persson H (1990) Molecular cloning and neurotrophic activities of a protein with structural similarities to nerve growth factor: developmental and topographical expression in the brain. Proc Natl Acad Sci USA 87:5454-5458.

Ernfors P, Bengzon J, Kokaia Z, Persson H, Lindvall O (1991) Increased levels of messenger RNAs for neurotrophic factors in the brain during kindling epileptogenesis. Neuron 7:165-176.

Gall CM, Isackson PJ (1989) Limbic seizures increase neuronal production of messenger RNA for nerve growth factor. Science 245:758-761.
Hallböök F, Ibañez CF, Persson H (1991) Evolutionary studies of the nerve growth factor family reveal a novel member abundantly expressed in Xenopus ovary. Neuron 6:845-858.

Hendry SHC, Jones EG, Emson PC, Lawson DEM, Heizmann CW, Streit P (1989) Two classes of cortical GABA neurons defined by differential calcium-binding protein immunoreactivities. Exp Brain Res 76:467-472.

Hofer M, Pagliusi SR, Hohn A, Leibrock J, Barde I-A (1990) Regional distribution of brain-derived neurotrophic factor mRNA in the adult mouse brain. EMBO J 9:2459-2464.

Hohn A, Leibrock J, Bailey K, Barde Y-A (1990) Identification and characterization of a novel member of the nerve growth factor/brainderived neurotrophic factor family. Nature 344:339-341.

Ip NY, Ibáñez CF, Nye SH, McClain J, Jones PF, Gies DR, Belluscio L, Le Beau MM, Espinosa E, Squinto SP, Persson H, Yancopoulos GD (1992) Mammalian neurotrophin-4: structure, chromosomal localization, tissue distribution, and receptor specificity. Proc Natl Acad Sci USA 89:3060-3064.

Isackson PJ, Huntsman MM, Murray KD, Gall CM (1991) BDNF mRNA expression is increased in adult rat forebrain after limbic seizures: temporal patterns of induction distinct from NGF. Neuron 6:937-948.

Jones KR, Fariñas I, Backus C, Reichardt LF (1994) Targeted disruption of the BDNF gene perturbs brain and sensory neuron development but not motor neuron development. Cell 76:989-999.

Kadekaro M, Crane AM, Sokoloff L (1985) Differential effects of electrical stimulation of sciatic nerve on metabolic activity in spinal cord and dorsal root ganglion in the rat. Proc Natl Acad Sci USA 82:6010-6013.

Kang H, Schuman EM (1995) Long-lasting neurotrophin-induced enhancement of synaptic transmission in the adult hippocampus. Science 267:1658-1662.

Kawaguchi Y, Katsumaru H, Kosaka T, Heizmann CW, Hama K (1987) Fast spiking cells in rat hippocampus (CA1 region) contain the calciumbinding protein parvalbumin. Brain Res 416:369-374.

Keller A, White EL, Cipolloni PB (1985) The identification of thalamocortical axon terminals in barrels of mouse Sml cortex using immunohistochemistry of anterogradely transported lectin (Phaseolus vulgarisleucoagglutinin). Brain Res 343:159-165.

Killackey HP (1973) Anatomical evidence for cortical subdivisions based on vertically discrete thalamic projections from the ventral posterior nucleus to cortical barrels in the rat. Brain Res 51:326-331.

Knipper M, Berzaghi MP, Blöchl A, Breer H, Thoenen H, Lindholm D (1994) Positive feedback between acetylcholine and the neurotrophins nerve growth factor and brain-derived neurotrophic factor in the rat hippocampus. Eur J Neurosci 6:668-671.

Korsching S (1993) The neurotrophic factor concept: a reexamination. J Neurosci 13:2739-2748.

Leibrock J, Lottspeich F, Hohn A, Hofer M, Hengerer B, Masiakowski P, Thoenen H, Barde Y-A (1989) Molecular cloning and expression of brain-derived neurotrophic factor. Nature 341:149-152.

Levi-Montalcini R (1987) The nerve growth factor: thirty-five years later. EMBO J 6:1145-1154.

Lindvall O, Ernfors P, Bengzon J, Kokaia Z, Smith M-L, Siesjo BK, Persson H (1992) Differential regulation of mRNAs for nerve growth factor, brain-derived neurotrophic factor and neurotrophin-3 in the adult rat brain following cerebral ischemia and hypoglycemic coma. Proc Natl Acad Sci USA 89:648-652.

Lohof AM, Ip NY, Poo M (1993) Potentiation of developing neuromuscular synapses by the neurotrophins NT-3 and BDNF. Nature 363:350-353.

Lu B, Yokoyama M, Dreyfus CF, Black IB (1991) Depolarizing stimuli regulate nerve growth factor gene expression in cultured hippocampal neurons. Proc Natl Acad Sci USA 88:6289-6292.

Maisonpierre PC, Belluscio L, Squinto S, Ip NY, Furth ME, Lindsay RM, Yancopoulos GD (1990) Neurotrophin-3: a neurotrophic factor related to NGF and BDNF. Science 247:1446-1451.

Melzer P, Van der Loos H, Dörfl J, Welker E, Robert P, Emery D, Berrini JC (1985) A magnetic device to stimulate selected whiskers of freely moving or restrained small rodents: its application in a deoxyglucose study. Brain Res 348:229-240.

Mizuno K, Carnahan J, Nawa H (1994) Brain-derived neurotrophic factor promotes differentiation of striatal GABAergic neurons. Dev Biol $165: 243-256$

Rocamora N, Palacios JM, Mengod G (1992) Limbic seizures induce a differential regulation of the expression of nerve growth factor, brain- 
derived neurotrophic factor and neurotrophin-3, in the rat hippocampus. Mol Brain Res 13:27-33.

Rocamora N, Welker E, Soriano E, Planas AM, Van der Loos H (1993) Upregulation of BDNF mRNA expression in the barrel cortex of adult mice following whisker stimulation. Soc Neurosci Abstr 19:259.

Rocamora N, Massieu L, Boddeke HWGM, Palacios JM, Mengod G (1994) Differential regulation of the expression of nerve growth factor, brain-derived neurotrophic factor and neurotrophin-3 mRNAs in adult rat brain after intrahippocampal injection of quinolinic acid. Mol Brain Res 26:89-98.

Rosenthal A, Goedded DV, Nguyen T, Lewis M, Shih A, Laramee GR, Niokolics K, Winslow JW (1990) Primary structure and biological activity of a novel human neurotrophic factor. Neuron 4:767-773.

Schwartz WJ, Smith CB, Davidsen L, Savaki H (1979) Metabolic mapping of functional activity in the hypothalamo-neurohypophysial system of the rat. Science 205:723-725.

Simons DJ (1978) Response properties of vibrissa units in rat SI somatosensory neocortex. J Neurophysiol 41:798-820.

Simons DJ (1985) Temporal and spatial integration in the rat SI vibrissa cortex. J Neurophysiol 54:615-635.

Snider WD (1994) Functions of the neurotrophins during nervous system development: what are knockouts teaching us. Cell 77:627-638.

Takeda A, Onodera H, Sugimoto A, Kogure K, Obinata M, Shibahara S (1993) Coordinated expression of messenger mRNAs for NGF, BDNF and NT3 in the rat hippocampus following transient forebrain ischemia. Neuroscience 55:23-31.

Van der Loos H, Woolsey TA (1973) Somatosensory cortex: structural alterations following early injury to sense organs. Science 179:395-398.

Van der Loos H, Welker E, Dörfl J, Rumo G (1986) Selective breeding for variations in patterns of mystacial vibrissae of mice: bilaterally symmetrical strains derived from ICR stock. J Hered 77:66-82.
Van Brederode JFM, Helliesen MK, Hendrickson AE (1991) Distribution of the calcium binding proteins parvalbumin and calbindin- $\mathrm{D}_{28 \mathrm{~K}}$ in the sensorymotor cortex of the rat. Neuroscience 44:157-171.

Welker C (1976) Receptive fields of barrels in the somatosensory neocortex of the rat. J Comp Neurol 166:173-189.

Welker E, Soriano E, Dörfl J, Van der Loos H (1989) Plasticity of the barrel cortex of the adult mouse: transient increase of GADimmunoreactivity following sensory stimulation. Exp Brain Res 78:659-664.

Welker E, Rao SB, Dörfl J, Melzer P, Van der Loos H (1992) Plasticity in the barrel cortex of the adult mouse: effects of chronic stimulation upon the deoxyglucose uptake in the behaving animal. J Neurosci 12:153-170.

Welker E, Armstrong-James M, Van der Loos H, Kraftsik R (1993) The mode of activation of a barrel column: response properties of single units in the somatosensory cortex of the mouse upon whisker deflection. Eur J Neurosci 5:691-712.

Zafra F, Hengerer B, Leibrock J, Thoenen H, Lindholm D (1990) Activity dependent regulation of BDNF and NGF mRNAs in the rat hippocampus is mediated by non-NMDA glutamate receptors. EMBO J 9:3545-3550.

Zafra F, Castrén E, Thoenen H, Lindholm D (1991) Interplay between glutamate and $\tau$-aminobutyric acid transmitter systems in the physiological regulation of brain-derived neurotrophic factor and nerve growth factor synthesis in hippocampal neurons. Proc Natl Acad Sci USA 88:10037-10041.

Zafra F, Lindholm D, Castrén E, Hartikka J, Thoenen H (1992) Regulation of brain-derived neurotrophic factor and nerve growth factor mRNA in primary cultures of hippocampal neurons and astrocytes. J Neurosci 12:4793-4799. 